\title{
ETNOBOTANI REMPAH TRADISIONAL DI DESA EMPOTO KABUPATEN SANGGAU KALIMANTAN BARAT
}

(Traditional Ethnobotany of Spices in the Village of Empoto, Sanggau District, West Kalimantan)

\author{
Yohanes Robi, Siti Masitoh Kartikawati, Muflihati \\ Fakultas Kehutanan Universitas Tanjungpura Pontianak, Jl. Daya Nasional Pontianak 78124 \\ E-mail : robbyaviver0712@gmail.com
}

\begin{abstract}
This study examines the ethnobotany of traditional spices in the Village of Empoto, Sanggau District, West Borneo. The research was conducted by interviewing, observing and making herbarium specimens. This study aims to record the plants spesies used as traditional spices, and explore the patterns utilization of plants as traditional spices by the pople in the village of Empoto, Sanggau District, West Kalimantan. As many as 59 plants species from 27 families are traditionaly used by the communities in Empoto village as traditional spices. The most widely used of plant family is Zingiberaceae (8 species). The highest utilization of plants as spices are derived from Dayak tribe, followed by Malay tribe and simultaneous utilization of this both tribe, $(100 \%, 28 \%$ and $28 \%$ respeetively). The pattern of utilization of spices used by the poeple in Empoto Village, Sanggau District, West Kalimantan is grouped into 7 patterns, namely spices as spices, flavour enhancers, aromatics, preservatives, naturalizers, softeners and coloring.
\end{abstract}

Keywords : Empoto Village, Ethnobotany, Traditional Spices

\section{PENDAHULUAN}

Etnobotani merupakan ilmu yang mempelajari hubungan antara manusia baik etnik ataupun kelompok masyarakat dan interaksinya dengan tumbuhan Kandowangko et al., (2011). Etnobotani dapat digunakan sebagai salah satu alat untuk mendokumentasikan pengetahuan masyarakat tradisional, masyarakat awam yang telah menggunakan berbagai macam tumbuhan untuk menunjang kehidupan. Seperti makanan, pengobatan, bahan bangunan, upacara adat, budaya, bahan pewarna dan lainnya. Semua kelompok masyarakat sesuai karakter wilayah dan adatnya memiliki ketergantungan pada berbagai tumbuhan (Suryadarma, 2008).

Indonesia merupakan negara yang memiliki kawasan hutan tropis terkaya nomor dua di dunia setelah Brazil dan masih menyimpan banyak potensi tumbuhan sebagai bahan pangan, obatobatan, bumbu dan rempah, bahan bangunan dan sebagainya. Rempah adalah bumbu yang berasal dari tumbuhan, baik segar maupun kering yang dicampurkan pada masakan sebagai penyedap (Soediarto et al., 1978).

Rempah-rempah adalah sumberdaya hayati yang sejak lama telah memainkan peran penting dalam kehidupan manusia. Rempah-rempah juga merupakan bagian tumbuhan yang bersifat aromatik dan dapat digunakan sebagai bumbu, penguat cita rasa, pengharum, dan pengawet makanan yang digunakan secara terbatas. Penggunaan rempah-rempah dalam seni kuliner telah diketahui secara luas yang 
berasal dari bagian batang, daun, kulit kayu, umbi, rimpang, akar, biji, bunga atau bagian-bagian tubuh tumbuhan lainnya (Duke et al., 2002).

Menurut De Guzman dan Siemonsma, (1999) bagian-bagian tubuh tanaman yang mengandung senyawa fitokimia yang dihasilkan tanaman sebagai bagian dari proses metabolisme tanaman. Adapun beberapa tanaman seperti adas, jinten dan ketumbar dimanfaatkan bagian bijinya sebagai rempah, untuk bagian rimpang, tanaman seperti jahe, kunyit, lengkuas, temulawak dan kapulaga umum digunakan, sedangkan jeruk, daun salam, seledri dan bawang dagian daunya dimanfaatkan sebagai rempah. Pemanfaatan rempah dapat diklasifikasikan dalam kategori rempah basah dan kategori rempah kering. Termasuk dalam kategori rempah kyering adalah lada, pala, jinten, ketumbar dan cengkeh. Golongan rempah basah antara lain meliputi kunyit, kencur, temu kunci, jahe, serai, bawang-bawangan, cabai dan lain sebagainya. Beberapa di antara yang sangat terkenal adalah cengkeh, lada, kayu manis, dan pala. Cengkeh sudah dikenal beratus-ratus tahun sebelum masehi, saat itu cengkeh digunakan untuk keperluan rempah-rempah dan wangi-wangian (Hadipoentyanti dan Rostiana, 1992).

Setiap daerah memiliki kekhasan dalam memanfaatkan tumbuhan untuk dijadikan rempah tradisional, seperti halnya pada masyarakat Desa Empoto di Kabupaten Sanggau Kalimantan Barat masih memanfaatkan tumbuh-tumbuhan yang diperoleh dari hasil kekayaan alam sekitar yang dimanfaatkan sebagai rempah tradisional seperti bumbu masakan, pengawet, pewarna, penguat cita rasa dan aromatik berdasarkan pengetahuan yang diwariskan secara turun temurun. Oleh karena itu dirasa penting untuk melakukan penelitian ini untuk mengetahui jenis tumbuhan apa saja yang dimanfaatkan oleh masyarakat Desa Empoto sebagai rempah tradisional serta bagaimana pola pemanfaatnya.

Penelitian ini bertujuan untuk mendata jenis-jenis tumbuhan yang digunakan sebagai rempah tradisional di Desa Empoto Kabupaten Sanggau Kalimantan Barat dan menggali pola pemanfaatn tumbuhan sebagai rempah tradisional di Desa Empoto Kabupaten Sanggau Kalimantan Barat.

\section{METODOLOGI PENELITIAN}

Penelitian ini dilaksanakan di Desa Empoto Kabupaten Sanggau Kalimantan Barat dan dilaksanakan selama lebih kurang 4 minggu. Kuisioner atau daftar pertanyaan sebagai alat utama pendukung pengumpulan data. Alat-alat yang digunakan adalah peta lokasi kegiatan penelitian, kamera, alat perekam suara. Objek dalam penelitian ini yaitu tumbuhan rempah itu sendiri serta masyarakat suku Dayak dan Melayu yang mengetahui jenis dan cara pemanfaatan tumbuhan yang digunakan sebagai rempah tradisional.

Teknik pengumpulan data pada penelitian ini dilakukan dengan metode wawancara, observasi dan pembuatan spesimen herbarium, data dikumpulkan dengan melakukan wawancara semi struktural dengan menggunakan kuisioner untuk menggali pengetahuan masyarakat tentang pola pemanfaatan tumbuhan 
rempah yang ada di Desa Empoto Kabupaten Sanggau Kalimantan Barat, pemilihan responden dilakukan dengan menggunakan metode snowball sampling dengan menetapkan Kepala Desa sebagai responden kunci. Diperoleh sebanyak 21 orang responden secara keseluruhan yang terbagi menjadi dua kelompok responden. Responden dari suku Dayak berjumlah 14 orang dengan umur berkisar antara 24-62 tahun, sebanyak 3 orang adalah laki-laki dan sebanyak 11 orang adalah perempuan, petani sebanyak 8 orang, ibu rumah tangga sebanyak 4 orang dan wiraswasta sebanyak 2 orang. Sedangkan responden dari suku Melayu berjumlah 8 orang dengan umur berkisar antara $32-69$ tahun, sebanyak 2 orang adalah laki-laki dan sebanyak 6 orang adalah perempuan, ibu rumah tangga sebanyak 5 orang, petani sebanyak 2 orang dan wiraswasta sebanyak 1 orang.

Observasi dilakukan untuk mengetahui jenis habitat dan habitus tumbuhan rempah dan pembuatan spesimen dilakukan untuk jenis-jenis tumbuhan yang belum diketahui nama ilmiahnya. Analisis data dilakukan dengan mengolah data yang diperoleh dari lapangan disusun dalam bentuk tabulasi dan dianalisis secara deskriftif serta identifikasi spesimen dilakukan dengan mempelajari buku dan jurnal penunjang identifikasi tentang etnobotani tumbuhan rempah.

\section{HASIL DAN PEMBAHASAN}

Hasil penelitian yang di lakukan di Desa Empoto Kabupaten Sanggau Kalimantan Barat tentang rempah tradisional yang dimanfaatkan oleh masyarakat terutama dari suku Dayak dan Melayu diperoleh sebanyak 59 jenis tumbuhan rempah dari 27 famili. Famili yang paling banyak dimanfaatkan berasal dari famili Zingberaceae (8 spesies) (Tabel 1).

Tabel 1. Jenis tumbuhan yang dimanfaatkan sebagai bumbu, penguat cita rasa dan aromatik oleh masyarakat di Desa Empoto (Plants species used by people in Empoto village as spices, reinforcing flavours and aromatics)

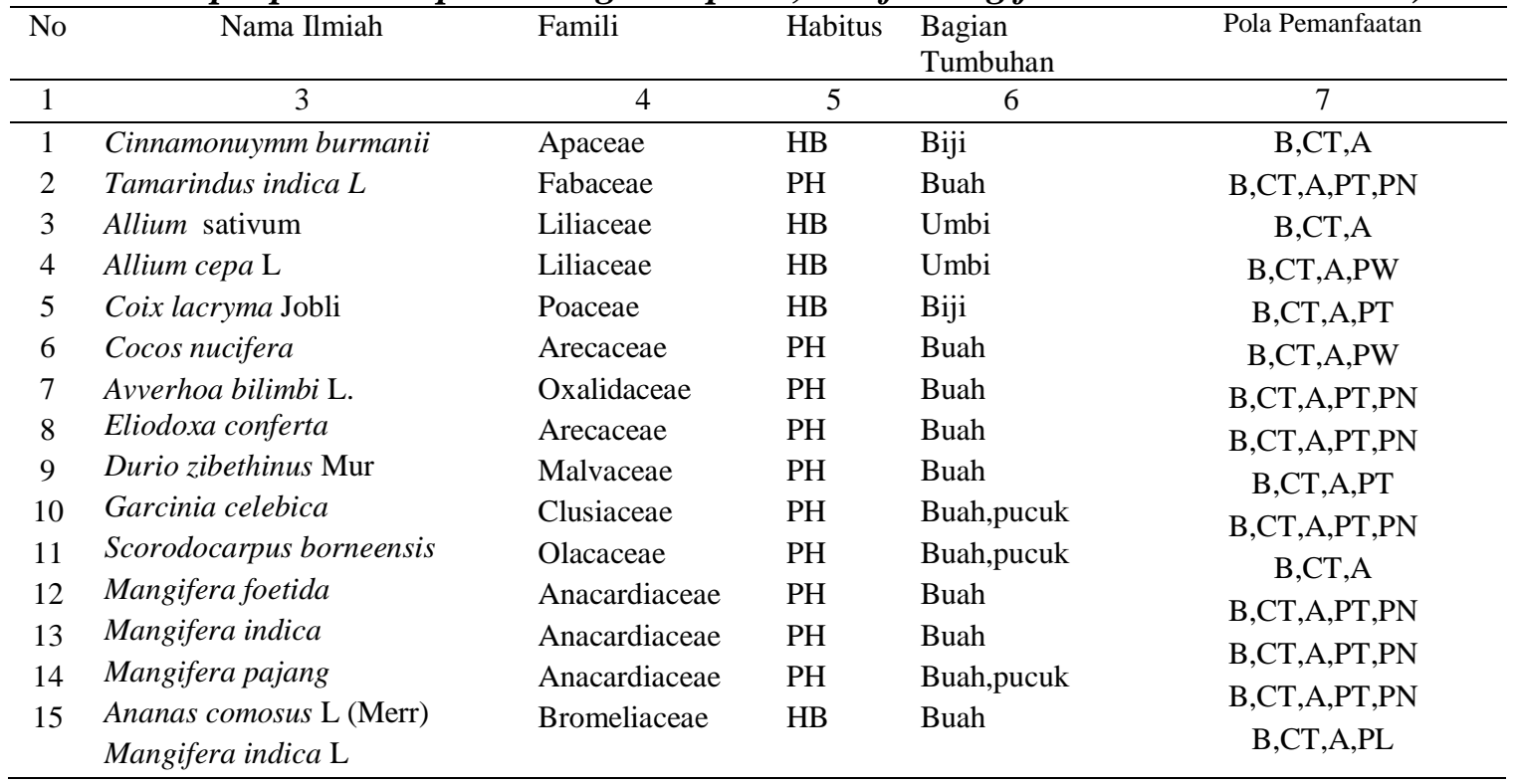




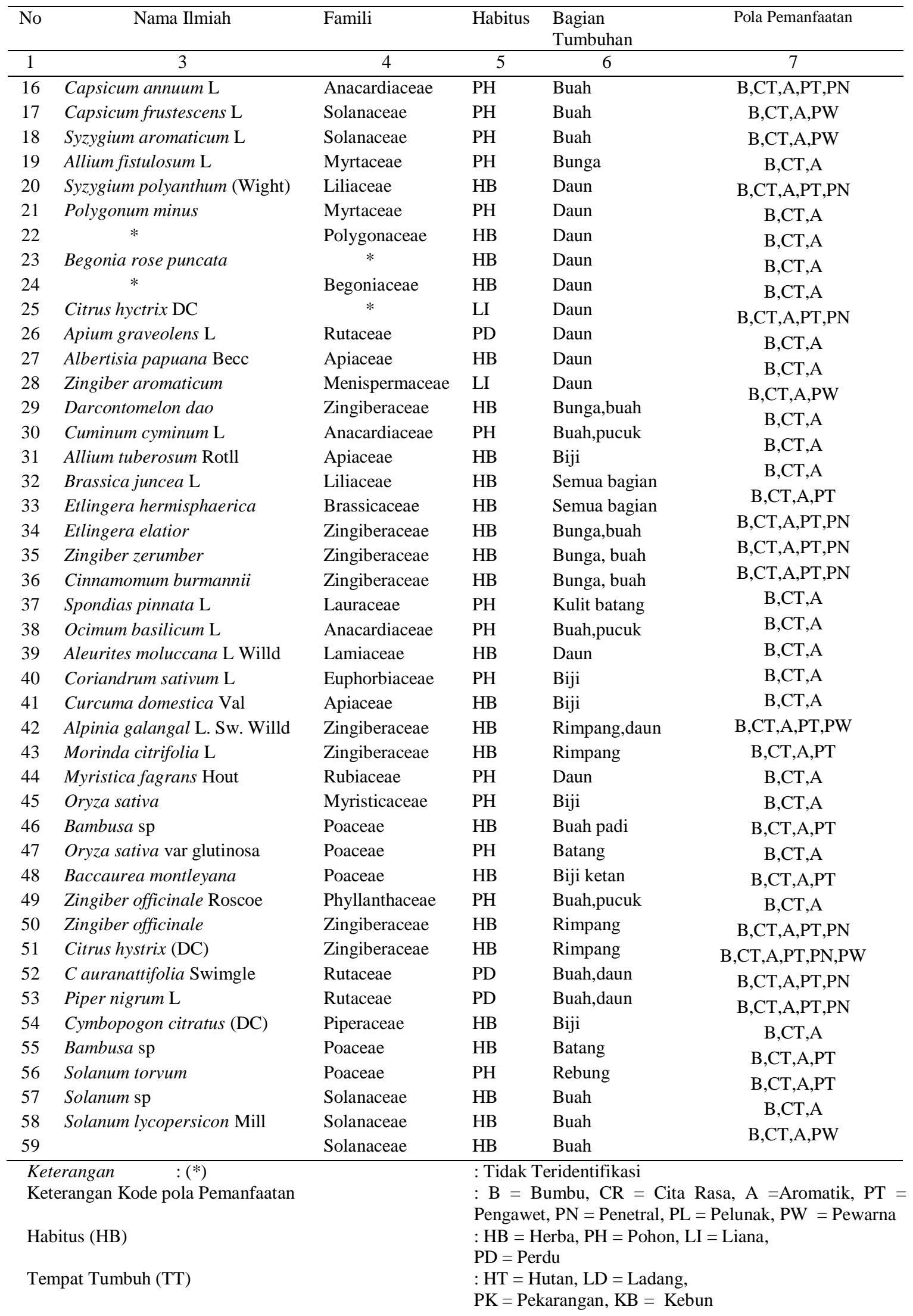


Jenis-jenis Zingiberaceae oleh sebagian besar masyarakat banyak dimanfaatkan sebagai bahan tambahan atau sebagai bumbu dan rempah dalam masakan misalnya kunyit, jahe, lengkuas, kecombrang dan sebagainya. 5 (lima) besar dari 27 (dua puluh enam) jumlah famili tumbuhan rempah yang ada di Desa Empoto terdiri dari famili Zingiberaceae (8 spesies), Poaceae (6 spesies), Anacardiaceae (6 spesies), Solananceae (5 spesies) dan Liliaceae (4 spesies).

Spesies Zingiberaceae yang banyak dimanfaatkan oleh masyarakat yang ada di Desa Empoto yaitu jenis kecombrang merah, kecombrang hijau, kunyit, lengkuas, jahe-jahean dan lain sebagainya, masyarakat di Desa Empoto memanfaatkan rempah jenis ini sebagai bumbu masakan yaitu sebagai penguat cita rasa, penetral rasa atau penghilang bau amis, pengharum/aromatik dan juga sebagai pewarna pada masakan.

Adapun manfaat rimpang jahe yaitu sebagai bumbu masakan, masyarakat Desa Empoto umumnya memanfaatkan jahe sebagai bahan campuran rempah tradisional pada masakan yang mampu menghasilkan cita rasa pedas gurih serta aroma wangi yang khas pada masakan. Sebagai pengharum dan penguat cita rasa, cara pemanfaatan jahe sebagai rempah tradisional penyedap rasa dan pewangi atau pemberi aroma pada masakan yaitu dengan cara mengambil jahe dari perkarangan rumah kemudian jahe di cuci bersih dan di tumbuk halus dengan rempah lain seperti bawang putih, bawang merah, kunyit, serai dan lain sebagainya untuk kemudian di masukan ke dalam masakan, ada juga yang di iris tipis dan di masukan pada masakan, jahe juga biasanya dimanfaatkan sebagai bahan lalapan yang mampu menghasilkan cita rasa pedas gurih dan segar serta mampu menghasilkan aroma wangi yang khas pada makanan dan masakan. Pernyataan ini juga selaras dengan pendapat Apriliani et al., (2014), yang menyatakan bahwa rimpang jahe dimanfaatkan sebagai penyedap rasa, pemberi aroma khas dan menghilangkan bau amis.

Jenis-jenis Poaceae banyak dimanfaatkan masyarakat Desa Empoto sebagai bahan utama permentasi makanan contohnya yaitu rebung masam berasal dari bambu muda (rebung) yang direndam dengan air selama beberapa hari sampai menghasilkan rasa masam untuk kemudian dimanfaatkan untuk memasak daging untuk menghasilkan cita rasa masam, selain itu serai merupakan famili Poaceae yang umum dijumpai dalam kehidupan sehari-hari yang dikenal sebagai bumbu penyedap pada masakan, hal itu juga sama dengan apa yang di lakukan oleh masyarakat Desa Empoto mereka memanfaatkan batang serai sebagai bumbu penguat cita rasa dan juag sebagai pengawet pada masakan. Hal demikian selaras dengan apa yang dikemukakan oleh Apriliani et al., (2014). Serai (C citratus (DC). dimanfaatkan sebagai rempah tradisional yang mampu menghasilkan cita rasa yang khas dan mampu 
mengkasilkan bau yang khas serta sebagai pengawet.

Sedangkan famili Anacardiaceae yang paling banyak dimanfaatkan oleh masyarakat yang ada di Desa Empoto yaitu buah mowa (asam mawang), buah pauh (asam pauh), buah maca (asam kemantan), kedondong, engkua (sengkuang), dan yang paling umum dijumpai dalam kehidupan sehari-hari adalah buah mangga, buah-buahan jenis ini banyak dimanfaatkan oleh masyarakat Desa Empoto karena mampu menghasilkan cita rasa masam gurih pada masakan serta mampu menghasilkan aroma wangi pada masakan.

Famili Solanaceae yang paling banyak dimanfaatkan oleh masyarakat yang ada di Desa Empoto sebagai bumbu rempah pada masakan yaitu tomat, tiua korak (terong pipit), tiua masep (terong masam), cabai keriting dan cabai rawit, jenis-jenis ini dapat dimanfaatkan masyarakat Desa Empoto sebagai penyedap pada masakan seperti tomat dimanfaatkan sebagai penghasil rasa masam, terong masam dimanfaatkan sebagai penghasil rasa masam, cabai dimanfaatkan sebagai penghasil rasa masam dan penghasil warna merah khususnya pada cabai yang sudah masak. Hal demikian selaras dengan apa yang dikemukakan oleh Apriliani et al., (2014). Cabai rawit (C frutescens L.) dimanfaatkan sebagai penyedap rasa yang mampu menghasilkan rasa pedas pada masakan.

$$
\text { Prasetyawati, (2010) juga }
$$
menyebutkan bahwa jika cabai dibelah, maka akan menemukan tangkai putih di dalamnya yang mengandung zat capsaicin yang seperti minyak dan menyengat sel-sel pengecap lidah. Zat inilah yang mengakibatkan cabai menjadi pedas dan panas di lidah ketika mengkonsumsinya serta membuat oprang ketagihan atau kecanduan saat menyantap makanan.

Sedangkan untuk famili Liliaceae yang paling banyak dimanfaatkan oleh masyarakat yang ada di Desa Empoto sebagai bumbu pada masakan yaitu jenis-jenis bawang putih, bawang merah, bawang kucai dan daun bawang, jenis-jenis rempah seperti ini sangat umum dijumai dan telah dikenal luas sebagai bumbu rempah pada masakan, masyarakat Desa Empoto juga memanfaatkan bumbu rempah jenis ini sebagai penghasil cita rasa pada masakan hal ini selaras denga pendapat Apriliani et al., (2014). Bawang putih (A sativum L) dimanfaatkan sebagai bumbu masakan, penyedap rasa dan aromatik. Wibowo (2006), menambahkan juga bahwa bawang putih memiliki cita rasa yang sangat khas yang ditimbulkan oleh komponen sulphur yang ada dalam minyak volatile bawang putih. Jenis senyawa yang menentukan bau khas bawang putih yaitu allicin.

\section{1). Jenis tumbuhan berdasarkan} Habitus

Berdasarkan habitus tumbuhan rempah yang ditemukan di lapangan, sebagian besar didominasi oleh tumbuhan herba $(47 \%)$ spesies, pohon (36\%), perdu (14\%) liana (3\%) spesies 
(Gambar 1). Salah satu contohnya jenis herba yang mendominasi adalah dari famili Zingiberaceae, alasan yang mendukung pernyataan ini yaitu karena menurut Ridley. (1967), Zingiberaceae merupakan tumbuhan herba yang hidup teresterial dan jarang tumbuh secara epifit. Tumbuhan dalam takson ini umumnya beraroma dan mempunyai rhizom (rimpang). Pemanfaatan Zingiberaceae oleh masyarakat umumnya untuk bumbu masakan, obatobatan tradisional, bahan makanan dan minuman serta pewarna makanan. Di
Sumatera Barat sendiri jenis-jenis Zingiberaceae yang paling umum dimanfaatkan adalah jenis $E$ cardamomum (kapulaga seberang/sabrang), $Z$ officinale (jahe merah), $C$ domestica (kunyit), $K$ galanga (kencur), A galanga (lengkuas). Jenis tersebut digunakan sebagai bumbu masak selain itu juga digunakan sebagai obat. Sementara di Kepulauan Mentawai semua jenis Zingiberaceae merupakan tumbuhan obat (Larsen et al., 1999).

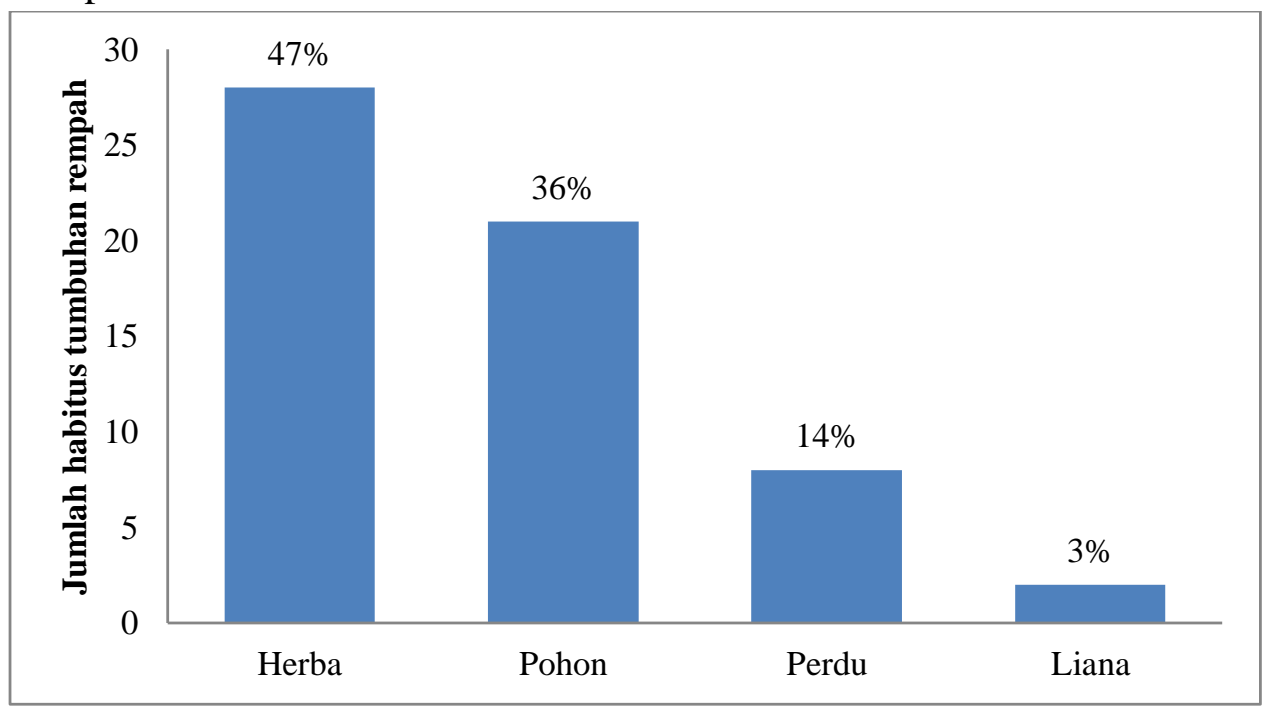

Gambar 1. Habitus tumbuhan rempah yang ada di Desa Empoto (Habitus of plants as spice in Empoto village)

\section{2). Bagian yang dimanfaatkan}

Bagian tumbuhan yang paling banyak dimanfaatkan dari ke 7 manfaat yang digunakan oleh masyarakat yang ada di Desa Empoto Kabupaten
Sanggau Kalimantan Barat yaitu rempah sebagai bumbu, penguat cita rasa, aromatik, pengawet, penetral, pelunak dan pewarna (Gambar 2). 


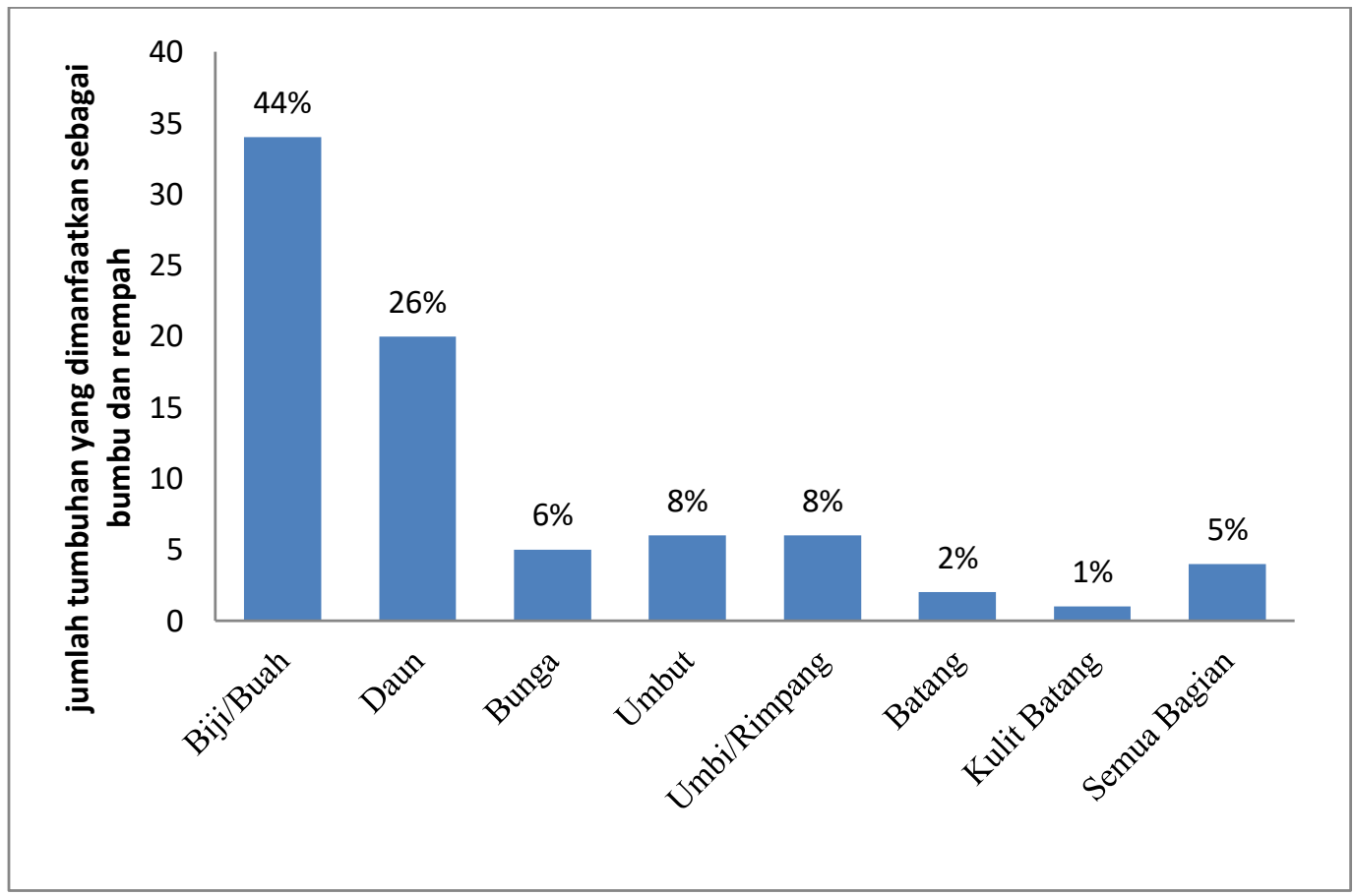

Gambar 2. Bagian-bagian tumbuhan yang dimanfaatkan sebagai bumbu dan rempah

(Plant parts that are used as herbs and spices)

Gambar 2 menunjukan bahwa bagian rempah yang paling banyak dimanfaatkan oleh masyarakat yang ada di Desa Empoto adalah bagian biji/buah yaitu sebanyak 34 spesies atau sebanyak (44\%) dan yang paling sedikit yaitu bagian rempah yang dimanfaatkan dari kulit batang yaitu hanya ada 1 spesies atau sebanyak (1\%) saja. Biji/buah paling banyak dimanfaatkan sebagai rempah karena memang biji/buah merupakan rempah yang umum dijumpai dalam kehidupan sehari-hari masyarakat di Desa Empoto yang di manfaatkan sebagai bahan bumbu dan rempah, diantaranya adalah sebagai berikut, pala, adas manis, jintan putih, kemiri, ketumbar, asam jawa, cabe, buah jeruk, rambai, nanas, belimbing, kelapa, tomat. Asam maram, asam pauh, asam kemantan, asam kandis dan lain sebagainya yang masing-masing memiliki cita rasa yang khas sebagai bumbu pada masakan. Sebagai salah satu contoh pernyataan yang mendukung data di atas ialah menurut Fatimah, (2017), adas manis memiliki wangi yang khas dan rasa yang manis. Ia mengandung komponen yang mirip akar manis. Adas manis aromanya harum dan tajam. Bentuknya seperti jintan, lebih bulat dan berwarna putih. Adas manis dijual dalam bentuk bubuk dan utuh. Sangrailah sebelum digunakan agar aroma lebih harum.

Bagian rempah yang dimanfaatkan oleh masyarakat Desa Empoto sebagai rempah yang memanfaatkan bagian kulit batang hanya ada satu jenis tumbuhan yang umum di jumpai sebagai bumbu dan rempah yaitu kulit batang kayu manis, kulit batang kayu manis tidak hanya di manfaatkan oleh mereka yang ada di sekitar pasar saja tetapi kayu manis juga 
dimanfaatkan oleh masyarakat yang ada di Desa Empoto sebagai bumbu dan rempah baik yang suku Melayu maupun yang suku Dayak.

Pernyataan di atas didukung oleh pernyataan dari Rismunandar, (1989) tanaman kayu manis ( $C$ burmanii) sudah lama dikembangkan di Indonesia dan merupakan salah satu komoditi rempah yang menjadi barang dagangan utama sejak zaman kolonial. Produk olahan kayu manis dapat dijadikan dalam bentuk bubuk, minyak atsiri, dan oleoresin. Oleoresin dan minyak atsiri dapat digunakan dalam industri makanan, minuman, farmasi, flavour (tembakau/rokok), fragrance, pewarna dan lain-lain. Sebagian besar senyawa yang terkandung dalam kulit batang kayu manis adalah minyak atsiri yang diteliti memiliki khasiat sebagai antibakteri yaitu Cinnamaldehyde dan Polifenol terdapat pada kulit batang dapat memberikan efek antibakteri. Keberadaan asam benzoat secara alami yang terdapat didalam tanaman buah rasberry, cengkih dan kayu manis, sangat umum digunakan sebagai bahan pengawet pada produk bahan pangan.

\section{3). Pola Pemanfaatan Tumbuhan}

\section{Rempah}

Menurut De Guzman dan Siemonsma, (1999) rempah-rempah adalah bagian tanaman yang berasal dari bagian batang, daun, kulit kayu, umbi, rimpang (rhizome), akar, biji, bunga atau bagian-bagian tubuh tumbuhan lainnya. Bagian-bagian tubuh tanaman tersebut mengandung senyawa fitokimia yang dihasilkan tanaman sebagai bagian dari proses metabolisme tanaman.
Pola pemanfaatan tumbuhan yang dimanfaatkan sebagai rempah tradisional di Desa Empoto Kabupaten Sanggau Kalimantan Barat dibagi menjadi 7 kelompok yaitu rempah sebagai bumbu masakan, penguat cita rasa, pengharum/aromatik, pengawet, penetral rasa dan bau (aroma), rempah sebagai pelunak daging dan pewarna:

\section{Pola Pemanfaatan Rempah Sebagai Bumbu Masakan, Rempah Sebagai Penguat Cita Rasa dan Rempah Sebagai Bahan Aromatik.}

Table 1 menunjukan bahwa hasil penelitian yang dilakukan di Desa Empoto menunjukan bahwa rempah yang dimanfaatkan oleh masyarakat Desa Empoto baik yang diperoleh dan dimanfaatkan secara tradisional maupun yang diperoleh melalui toko/pasar menunjukan bahwa sebanyak 59 spesies rempah yang dimanfaatkan sebagai bumbu masakan, sebagai penguat cita rasa dan sebagai bahan aromatik.

\section{Pola Pemanfaatan Rempah Sebagai Pengawet Makanan}

Beberapa spesies tumbuhan yang dimanfaatkan sebagai pengawet makanan yaitu sebanyak 26 spesies, dengan famili terbanyak yaitu Zingiberaceae (7 spesies), Poaceae (5 spesies), Anacardiaceae (4 spesies), Rutaceae (3 spesies) dan yang lainnya masing-masing (1 spesies. Habitus yang paling banyak berupa herba (12 spesies), pohon (10 spesies) dan perdu (4 spesies). Bagian yang paling banyak di manfaatkan adalah biji/buah (17 spesies), daun (5 spesies), rimpang (4 spesies) dan ada 2 spesies yang mengguanakan semua bagian tumbuhan. jenis tumbuhan yang mendominasi yaitu tumbuhan yang 
menghasilkan cita rasa masam pada masakan karena rasa masam mampu memberikan efek segar serta mampu mengawetkan makanan khususnya pada daging, jenis spesies tumbuhanya yaitu, lengkuas, asam kandis, asam jawa, jeruk nipis, jeruk purut, boncik, rimpang tapai, nasi dingin, rebung asam, pekasam sawi, tempoyak, terong asam dan lain sebagainya.

Salah satu data yang mendukung pernyataan di atas yaitu menurut Rahayu (1999) menyatakan bahwa rimpang lengkuas rasanya tajam pedas, menggigit dan berbau harum karena kandungan minyak atsirinya. Rimpang lengkuas dapat dimanfaatkan sebagai pengawet yaitu dengan cara rimpang diparut dan di sangrai biasanya dijadikan serundeng ayam. Menyebutkan bahwa extrak lengkuas memiliki aktifitas terhadap 5 bakteri uji yang umum mengkontaminasikan makanan yaitu Vibrio cholera, Pseudomonas aeruginosa, Listeriamonocytogenes, Staphylococcus aures dan Bacillus cereus serta pada 3 kapang perusak pangan yaitu Aspergillus flavus,Rizopus oligosporus dan Penicillium funiculosum.

\section{Pola Pemanfaatan Rempah Sebagai Penetral Rasa/Bau (Aroma)}

Sebanyak 17 spesies tumbuhan rempah yang dimanfaatkan sebagai penetral rasa/bau pada makanan dan masakan, famili yang paling banyak di manfaatkan yaitu Zingiberaceae (5 spesies), Anacardiaceae (4 spesies), Rutaceae (3 spesies) dan yang lainnya masing-masing 1 spesies. Habitus tumbuhan yang paling banyak di manfaatkan adalah pohon (8 spesies), herba (5 spesies) dan perdu (4 spesies). Sedangkan bagian yang paling banyak dimanfaatkan adalah buah (13 spesies), daun (6 spesies) dan umbut (3 spesies). Rempah yang biasanya banyak dimanfaatkan yaitu rempah yang menghasilkan cita rasa masam seperti asam kandis, belimbing wuluh buah jeruk dan lain sebagainya. Pemanfaatan jeruk sebagai penghilang bau amis ditegaskan oleh Razak et al., (2013), menyebutkan bahwa keasaman pada buah jeruk sambal disebabkan oleh kandungan asam organik berupa asam sitrat. Bagian buah selain sebagai pengasam bisa juga dimanfaatkan untuk penghilang bau amis, caranya yaitu buah diperaskan ke bagian ikan atau daging yang akan dimasak. Tanaman marga Citrus merupakan salah satu tanaman penghasil minyak atsiri yang merupakan suatu substansi alami yang telah dikenal memiliki efek sebagai antibakteri dan menghasilkan aroma yang khas. Pemanfatan buah jeruk purut sebagai penghilang bau amis yaitu diperas dan lumuri kebagian daging atau ikan. (Mayasari et al., 2013).

\section{Pola Pemanfaatan Rempah Sebagai Pelunak Daging}

Terdapat 1 spesies tumbuhan rempah yang dimanfaatkan sebagai pelunak daging, contoh tumbuhannya adalah olahan buah nanas yang apabila di masak dengan daging yang mempunyai tekstur yang keras akan menjadi cepat lunak apabila dimasak secara bersamaan dengan buah nanas.

Salah satu manfaat buah nanas yang telah banyak digunakan oleh masyarakat adalah sebagai bahan pengempuk daging. Enzim bromelin dapat diekstrak dari 
bagian batang atau hati buah nanas. Aktivitas enzim bromelin dari nanas terbukti dapat mempertahankan mutu fisik daging. Enzim bromelin sering

Tabel 2. Spesies rempah yang dimanfaatkan sebagai pelunak daging (Plants as

dimanfaatkan dalam usaha pengempukan daging karena kemampuan proteolitiknya dapat menghidrolisis ikatan peptida dalam daging (Anam, 2003).

\begin{tabular}{|c|c|c|c|c|c|}
\hline & & & & & \\
\hline No & $\begin{array}{c}\text { Nama Lokal } \\
\text { dan Nama } \\
\text { Umum }\end{array}$ & Nama Ilmiah & Famili & Habitus & $\begin{array}{c}\text { Bagian yang } \\
\text { Digunakan }\end{array}$ \\
\hline
\end{tabular}

\section{Paot (Nanas) A comosus L. (Merr). \\ 5. Pola Pemanfaatan Rempah Sebagai Penghasil Warna}

Sebanyak 9 spesies tumbuhan rempah yang dimanfaatkan sebagai penghasil warna alami pada makanan dan masakan, family yang paling mendominasi yaitu Zingiberaceae (4 spesies), Solanaceae (3 spesies) dan yang lainnya masing-masing (1 spesies). Habitus yang mendominasi adalah herba (6 spesies), perdu (2 spesies) dan pohon (1 spesies). Bagian tumbuhan yang paling banyak dimanfaatkan adalah buah (4 spesies), bunga dan rimpang masing-masing (2 spesies) dan umbut (1 spesies). Contoh tumbuhannya adalah cabai merah memberikan efek warna merah pada masakan, bunga kecombrang merah memberikan efek warna merah pada masakan, kunyit memberikan efek warna kuning orange pada masakan, bunga engkareh memberikan efek warna merah pada masakan, santan kelapa memberikan efek warna putih pada kuah masakan dan lain sebagainya.

Apriliani et al., (2014). Kelapa ( $C$ nucifera) merupakan salah satu contoh yang mendukung data di atas menyebutkan bahwa masyarakat di Desa Tamao Kecamatan Embaloh Hulu Kapuas Hulu Kalimantan Barat

$\begin{array}{ccl}\text { Bromeliacecae } & \text { Herba } & \text { Buah } \\ \text { memanfaatkan air dan daging } & \text { kelapa }\end{array}$

sebagai pewarna, penyedap rasa, pemberi aromatik pada masakan. Hal ini sesuai dengan pernyataan Kort (1979) bahwa santan merupakan emulsi lemak dalam air dan dapat berwarna putih susu karena partikelnya berukuran lebih besar dari satu micron. Santan distabilisasi secara alamiah oleh protein (globulin dan albumin) dan fosfolipida.

\section{Kesimpulan}

1. Jenis tumbuhan rempah tradisional yang dimanfaatkan oleh masyarakat di Desa Empoto Kabupaten Sanggau Kalimantan Barat sebanyak 59 spesies dari 27 Famili. Famili yang paling banyak dimanfaatkan sebagai rempah tradisional yaitu family Zingiberaceae sebanyak 8 spesies yaitu seperti engkareh ( $Z$ aromaticum), kecombrang hijau ( $E$ hermisphaerica), kecombrang merah ( $E$ elatior), kancok ( $Z$ zerumber), kunyit ( $C$ domestica Val), lengkuas (A galangal L. Sw. Willd), jahe bumbu ( $Z$ officinale Roscoe), jahe merah ( $Z$ officinale).

2. Pola pemanfaatan rempah yang ada di Desa Empoto Kabupaten Sanggau Kalimantan Barat di bagi menjadi beberapa pola yaitu paling banyak 
dimanfaatkan sebagai bumbu masakan, sebagai penguat ciat rasa, sebagai bahan aromatik, sebagai penetral rasa, sebagai pewarna alami, sebagai pelunak, dan yang paling sedikit yaitu dimanfaatkan sebagai pengawet yang hanya 1 spesies.

\section{Saran}

Perlu adanya kesadaran dari masyarakat setempat dalam melestarikan dan membudidayakan jenis-jenis rempah yang langka dan berpotensi sebagai penunjang perekonomian masyarakat setempat seperti daun empareh/sengkubak/daun micin, buah kuduar, daun kopiat, daun pulanua, daun kuru dan lain sebagainya. Perlu adanya penelitian lanjutan untuk mengetahui kandungan kimia pada tumbuhan rempah tradisional yang ada di Desa Empoto Kabupaten Sanggau Kalimantan Barat apakah tumbuhan tersebut dapat dikonsumsi atau tidak dengan cara pengolahan yang praktis, sehingga pemanfaatan rempah secara tradisional tetap menjadi pilihan utama masyarakat.

\section{DAFTAR PUSTAKA}

Anam, C., N, S. Rahayu, dan M, Baedowi. 2003. Aktivitas Enzim Bromelin terhadap Mutu Fisik Daging. Seminar Nasional dan Pertemuan Tahunan Perhimpunan Ahli Teknologi Pangan Indonesia (PATPI). Yokyakarta.

Apriliani A, Sukarsa, Hidayau AH. 2014. Kajian Etnobotani Tumbuhan Bahan Tambahan Pangan Secara Tradisional Oleh
Masyarakat di Kecamatan Pekuncen Kabupaten Banyumna. Fakultas Biolongi, Universitas Jendral Soedirman.vol 1 hal76-84.

De Guzman CC and J.S Siemonsma. 1999. PROSEA-Plant Resources of South-East Asia No. 13. Spices.

Duke JA., M. Jo Bogenschutz-Godwin, J. Du Cellier and PAK Duke. 2002. Handbook of Medial Spices. CRC Press.

Fatimah NR. 2017. Mari mengenal bumbu nusantara. Jakarta: Badan Pengembangan dan Pembinaan Bahasa.

Hadipoentyanti, E. dan O. Rostiana. 1992. Pemanfaatan Tanaman Rempah Dalam Kehidupan Masyarakat Indonesia. Dalam: Nasution, R.E., S. Riswan, P. Tjitropranoto, E.B. Walujo, W. Martowikrido, H. Roematyo dan S.S. Wardoyo (eds.). Prosiding Seminar dan Lokakarya Nasional Etnobotani, Departemen Pendidikan Dan Kebudayaan R.I., Departemen Pertanian R.I., LIPI dan Perpustakaan Nasional; Cisarua, Bogor, 19-20 Pebruari 1992.

Kandowangko N., Solang M. dan Ahmad J. 2011. Kajian Etnobotani Tumbuhan Obat oleh Masyarakat Kabupaten Bonebolango Provinsi Gorontalo. Fakultas Biologi FMIPA UNG.

Kort MJ. 1979. Colour in the sugar industry. Duban, South Africa: 
Sugar Milling Research Institute, University Of Natal.

Larsen. K, H. Ibrahim, S. H Khaw and L. G. Saw. 1999. Gingers of Peninsular Malaysia and Singapore. Natural history publication (Borneo). Kinabalu. Sabah. Malaysia.

Mayasari D, Afghani J, Wibowo MA. 2013. Pengaruh variasi waktu dan ukuran sampel terhadap komponen minyak atsiri dari daun jeruk purut (Citrus Hystrix Dc.). Pontianak. JKK. 2(2): 74-77.

Prasetyawati NP. 2010. Analisa kandungan vitamin $\mathrm{C}$ pada cabai rawit (Capsicum Frustescens L.) berbagai varietas. Universitas Muhamadiyah SemarangSemarang.

Radiarti L. 2002. Mekanisme penghambatan virulensi bakteri enteropatogen oleh ekstrak rimpang jahe (Zingiber officinale Roscoe.) Institut Pertanian BogorBogor.

Razak A, Djamal A, Revilla G. 2013. Uji daya hambat air perasan buah jeruk nipis (Citrus aurantifolia L.) terhadap pertumbuhan bakteri Staphylococcus aureus secara in vitro. Jurnal Kesehatan Andalas. 2(1). 2301-7406

Ridley. N. H. 1967. The Flora of The Malay Peninsula. L Reeve \& Co. Ltd London. England.
Rismunandar. 1987. Lada, budidaya dan tata niaganya. Jakarta: Penebar Swadaya.

Soediarto, A., E. Guhardja, dan H. Sudarmadi. 1978. Bumbu dan Rempah. Bogor: Departemen Ilmu dan Kesejahteraan Keluarga Pertanian, IPB.

Suryadarma, I.G.P. (2008). Peran Hutan Masyarakat Adat dalam Menjaga Stabilitas Iklim Satu Kajian Perspektif Deep Ecology (Kasus Masyarakat Desa Adat Tenganan, Bali). Jurnal Konservasi Flora Indonesia Dalam Mengatasi Dampak Pemanasan Global. Hal 50-56.

Wibowo S. 2006. Budidaya bawang, bawang putih, bawang merah, bawang bombay. Jakarta: Penebar Swadaya. hal 80-81. 